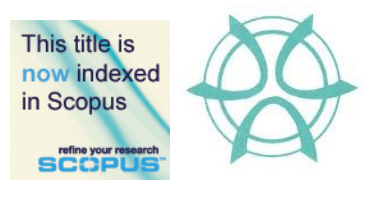

PLANNING MALAYSIA:

Journal of the Malaysian Institute of Planners

VOLUME 16 ISSUE 3 (2018) Page 143 - 155

\title{
TEMPORARY PLANNING PERMISSION IN DEVELOPMENT CONTROL SYSTEM FOR URBAN DEVELOPMENT
}

\author{
Mohammad Yusup ${ }^{1}$, Ahmad Fuzi Arshad ${ }^{2}$, Marlyana Azyyati Marzukhi \\ \& Yusfida Ayu Abdullah ${ }^{4}$ \\ ${ }^{1,2,3,4}$ Faculty of Architecture, Planning and Surveying \\ UNIVERSITI TEKNOLOGI MARA, MALAYSIA
}

\begin{abstract}
Planning permission is prerequisite in development control process as it acts as one of the most significant and effective factors that determine the quality built environment and physical planning. This paper focuses on the temporary planning permission, which is a short-term approval and is only permissible for temporary use of land and buildings. The potential advantages of temporary planning permission have yet to be explored by the planning authorities in Malaysia. This study is aimed at exploring the implementation of the planning permission delivery process in controlling the development of land and building on a temporary basis. Thus, the objectives are intended to examine the process and procedure of temporary planning permission for urban development in relation to Act 172, to ascertain the role and function of the local planning authority, and reviewing the provision of law related to the temporary planning permission as in the Act 172. Comparative analysis between Act 172 (West Malaysia), Planning Act (Cap. 232) (Singapore) and Town and Country Planning Act 1990 (UK) in terms of decision making process has been made to explore the best practices in temporary planning permission. This study is anticipated to enhance the temporary planning permission delivery process and the development control system in Peninsular Malaysia.
\end{abstract}

Keywords: development control system, local planning authority, planning law, temporary planning permission, urban development, urban governance 
Mohammad Yusup, Ahmad Fuzi Arshad, Marlyana Azyyati Marzukhi, \& Yusfida Ayu Abdullah

Temporary Planning Permission in Development Control System for Urban Development

\section{INTRODUCTION}

Town planning is envisioned in shaping a good quality of living and working environment, to facilitate the economic development, as well as promoting health, safety, convenience and general welfare of the people through development control and the use of land (Hong Kong Planning Department, 2015)(Hong Kong Planning Department, 2015). Town planning key roles are to perform forward planning (for the future), presently controlling the development, and pondering upon the development that has taken place as guidance for current and future gain (Arshad, 2015) (Arshad, 2015) (Figure 1).

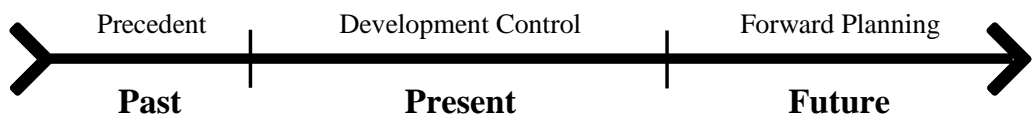

Figure 1: Planning Time-Frame Source: Adapted from Arshad (2015)

The term 'town planning' itself embraces two important keywords; planning and development. Basically, planning was introduced to assure a good living environment and wellbeing of the people (Zainol, 2009)(Zainol et al., 2009). Subsection 2(1) of the Town and Country Planning Act 1976 (Act 172) defined the term 'development' as the carrying out of any building, engineering, mining, industrial or other similar operation in, on, or under land, the making of any material change in the use of any land or building or any part thereof, or the subdivision or amalgamation of lands: and 'develop' shall be interpreted accordingly. From the above definition, development can be divided into three categories, which are operational work, material change of use and land matters (Arshad, 2015) (Table 1).

Table 1: Act 172 category and scope of development

\begin{tabular}{l|rlll}
\hline Category & & \multicolumn{3}{|c}{ Scope } \\
\hline Operational works & $\bullet$ & Building & $\bullet$ & Mining \\
& $\bullet$ & Engineering & $\bullet$ & Industrial \\
& $\bullet$ & Earthwork & \\
\hline Material change of use & $\bullet$ & Physical & $\bullet$ & Relevant \\
& $\bullet$ & Substantial & \\
\hline Aspects in land & $\bullet$ & Conversion of use & $\bullet$ & Amalgamation \\
administration & $\bullet$ & Change of conditions & $\bullet$ & Partitioning \\
& $\bullet$ & Subdivision & \\
\hline
\end{tabular}

Source: Arshad (2015)

The operational work is defined as any work that involves physical changes and taken place on land and/or buildings (Arshad, 2010), and classified into building works, engineering works, earthworks, industrial works and mining 
works. Building works operation is making changes or construction of the structure whichever involves the whole or part of the building and it is either attached or detached to the ground and also including demolition of buildings (Arshad, 2010). However, in Malaysia, the definition of mining work operation is still not clearly specified in the National Land Code Act 1965 (Act 56) and Act 172. Thus, to make it clearer, the definition of mining work operation for this paper is adapted from the Physical Planning and Development Control Act (No. 25 of 2002) (Act 25) of Grenada that defined 'mining operation' as the carrying out in relation to any mineral or substance (including oil and geothermal energy) in or under the land of any activity with a view in searching for, removing by underground or surface working, carrying away, treating or converting that mineral, and including the removal of beach sand, quarrying, drilling and boring operations. On the other hand, the material change of use involves a change to the use of land and/or buildings or any part thereof defined by Arshad (2010). The term 'material' can be divided into three; physical, substantial (massive and clear changes to the land and/or building) and relevant (related to planning). Finally, the land administration aspect involves the conversion of use, change of conditions, subdivision, amalgamation and partitioning. In essence, there are five criteria in determining an activity executed or material change as development, and therefore require planning permission (Arshad, 2010) (Table 2).

Table 2: The criteria of development

\begin{tabular}{l|ll}
\hline \multicolumn{1}{c|}{ Criteria } & \multicolumn{1}{c}{ Justification } \\
\hline Type of use & $\bullet \begin{array}{l}\text { More relative because the classification is clear and can be } \\
\text { distinguished according to the law }\end{array}$ \\
\hline $\begin{array}{l}\text { Intensification of } \\
\text { use }\end{array}$ & $\bullet \begin{array}{l}\text { The situation in which activities or uses being performed as } \\
\text { an ancillary or incidental to the parent use }\end{array}$ \\
\hline Abandonment & $\bullet$ & Comprising the discontinuation of use \\
\hline Multiple uses & $\bullet$ & Consists of more than one ancillary use of parent use \\
\hline $\begin{array}{l}\text { Development } \\
\text { unit }\end{array}$ & $\bullet \quad$ Can be recognized as a single development unit \\
$\begin{array}{l}\text { Source: Arshad (2010) } \\
\end{array}$
\end{tabular}

In planning and development, having an excellent development control system is the key towards the competency of the local planning authority (LPA) in deciding over the physical development of its area. Development control, therefore, is required for every physical development that took place on land and/or buildings. It is a method used by LPA in controlling the development within its administrative area (Zainol, 2000). Hence, it can be said that development control is the process of assessing and processing planning application before granting the planning permission for any land development (Yusup, 2013)(Yusup, 2013). 
Mohammad Yusup, Ahmad Fuzi Arshad, Marlyana Azyyati Marzukhi, \& Yusfida Ayu Abdullah

Temporary Planning Permission in Development Control System for Urban Development

Planning permission, according to Subsection 2(1) of Act 172, is expressed as permission granted, either with or without conditions applied, to carry out development. It is a legal document issued by the LPA of the area, which allows specific development at a particular site (Leicester City Council, 2015)(Leicester City Council, 2015).

\section{DEVELOPMENT CONTROL: THE INSTRUMENTATION IN DECISION-MAKING PROCESS}

The development control approach consists of two main mechanisms, namely statutory and non-statutory planning instruments (Arshad, 2010). The statutory development control mechanisms are formed by the legal provisions and the approval procedures by the authority of the respective areas. It is the gazetted and approved documents according to the legal procedure and usually prepared by systematic procedure and approval period. However, the non-statutory development control mechanisms are the non-gazetted documents exercised for the purpose of the planning and development control. This type of development control mechanism helps in supporting the statutory development control mechanism and facilitates the implementation of development control functions by LPA. This shows that development control can be in various forms of approaches and the main aim is to control the development of land and buildings.

\section{PLANNING PERMISSION: WHY IS IT NECESSARY?}

The requirement for planning permission by the Act 172 is spelt out under Section 18 to Section 31A of Part IV - Planning Control. Planning permission can be seen as the process in allowing any activity to take place on land and buildings or to permit any change on the use of land and buildings (Arshad, 2015). The planning permission is indeed necessary so as to control proper development of land and buildings and to implement the proposals of the development plan accordingly.

\section{LPA Roles in Planning Permission Process}

The local authority is the lowest level of the government administration system and this position allows them to regulate and monitor the development process within their respective territory (Yusup, 2013)(Yusup, 2013). Subsection 5(1) of Act 172 affirms that every local authority shall act as the LPA within their administrative area. While, any other area that is not under the jurisdiction of the local authority, Section 5(2) of the same Act provides the legislative power to the State Director as the LPA of the area and perform such functions as the LPA as stipulated in Section 6(1) of Act 172. These include to regulate, control and plan for the development and the use of all land and buildings within their respective administrative area. Moreover, LPA also carried out functions like undertaking, assisting in, and encourage the collection, maintenance, and publication of statistics, bulletins, and monographs, and other publications relating to town and 
PLANNING MALAYSIA

Journal of the Malaysia Institute of Planners (2018)

country planning and its methodology. The LPA also perform such other functions as assigned by the State Authority or the State Planning Committee from time to time as well as functions specified in Section 6(2).

Section 4(4) (aa) of Act 172 also points out that the SPC is also responsible in regulating, controlling, plans and organises all development activities within the state administrative area. Thus, the role of local authority as LPA is shared or duplicated with the SPC with regard to development control matters. In addition, Section 22(2A) of the same Act states that SPC may request advice from the National Physical Planning Council (NPPC) regarding certain types of development whose planning application are submitted to LPA.

\section{The Planning Permission Process and Procedure}

Figure 2 shows planning permission process and procedure as stipulated in Act 172. In short, any new proposed development, either permanent or temporary, must conform to the existing development plan of the area. Irrespective whether or not the plan has been gazette, planning applications must refer to the said development plan. However, the period when development plan has yet to be gazette tend to put the LPA in a dilemma when it comes to deciding on planning applications. The question is how to decide on the planning application at this period of time?

There are several ways in enhancing the decision-making process that can be performed by the LPA which include through the issuance of temporary planning permission (TPP) especially for a short-term time-based development of land and building that may not give obvious impact towards its physical, social and economic aspects of the surrounding area. Alternatively, LPA development control system could adapt to use a non-statutory approach or informal method by creating procedures to formalise the non-statutory or informal instruments such as applying elements of participation, consultations with professional agencies and adoption by the councils. 
Mohammad Yusup, Ahmad Fuzi Arshad, Marlyana Azyyati Marzukhi, \& Yusfida Ayu Abdullah Temporary Planning Permission in Development Control System for Urban Development

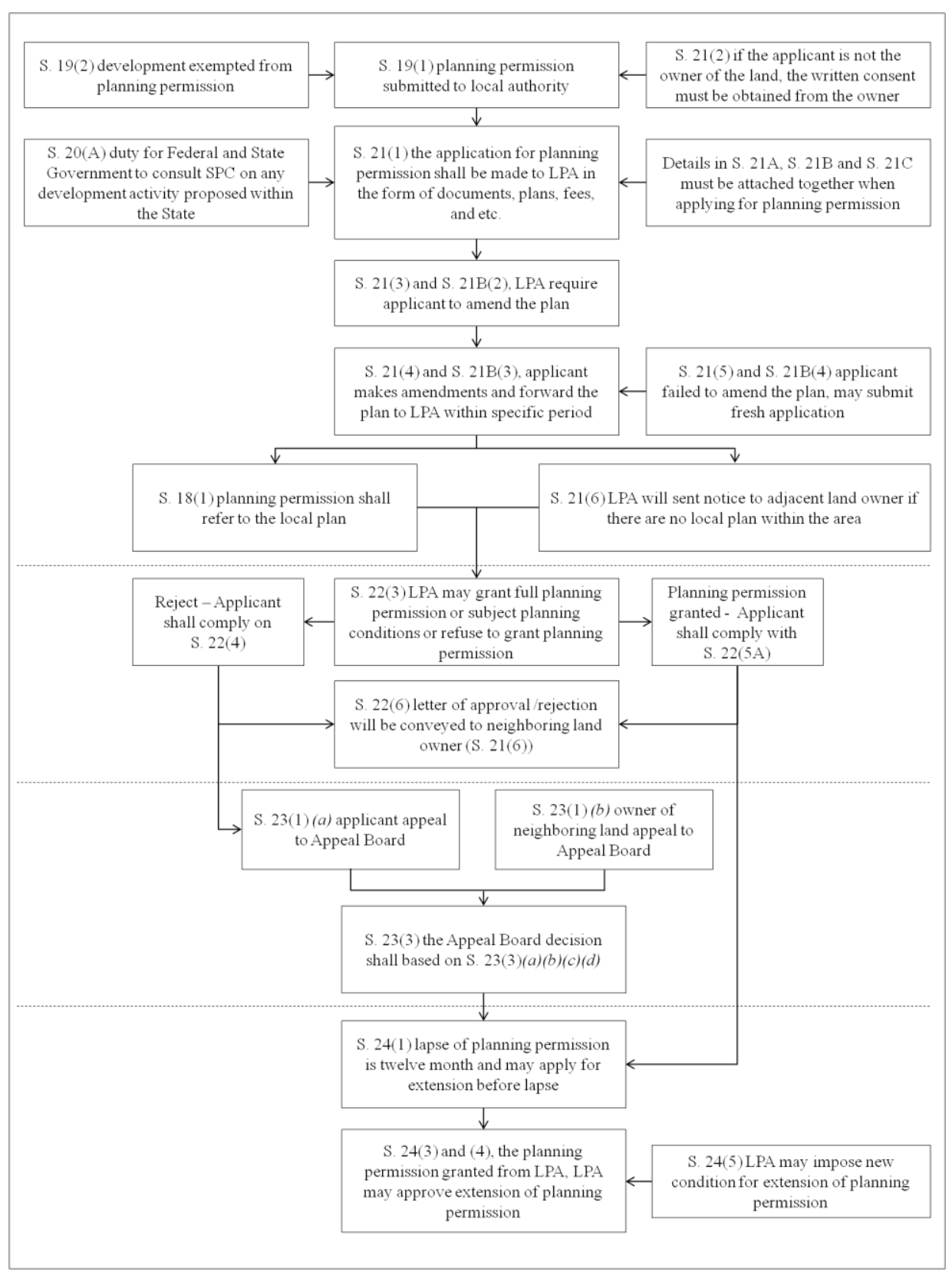

Figure 2: Planning permission process and procedure as stipulated in Act 172 Source: Adapted from Arshad (2012) 
PLANNING MALAYSIA

Journal of the Malaysia Institute of Planners (2018)

\section{TEMPORARY PLANNING PERMISSION (TPP) AND ITS PROVISION IN ACT 172}

The temporary planning permission (TPP) is basically a short-term, time-based planning permission, which can be extended or revoked by the LPA at any time which the LPA thinks necessary for the protection of public interest in the area (Arshad, 2015). Usually, the TPP period can be up to a maximum of five years. The approval for this type of planning permission is granted by the LPA for a fixed time period on which it will expire based on the stipulated planning conditions (Arshad, 2015). The LPA may grant the TPP due to the proposed structure or the use of land and/or building is impermanent and the LPA might also remove the structure or stop the use of land and/or buildings when it is no longer necessary(Magrath Insight, 2012). Additionally, the LPA can also grant the TPP if they are uncertain regarding the impact of the use of land and/or building and intended to give the development a 'trial run'(Magrath Insight, 2012). As an example, coastal reclamation can be considered as a 'new land'. After the reclamation has taken place, the area should not straight away be developed with permanent development as the land is still unstable and takes time to be stabilised. Therefore, during that period, the LPA can propose or grant any temporary development on the land as a 'trial run' to see the impact and effect in carrying out development on the land. This 'trial run' also can be an effective way to see the strength, weakness, opportunity and threat of the area in order to plan for a long-term future development.

There are various areas of development or categories of land use and building use that TPP can be applied such as commercial (kiosk, car showroom), industrial (futsal arena), agriculture, residential, recreational, public facilities, public infrastructure (telecommunication tower), utilities, amenities and archaeological site based on its suitability with the requirement where the TPP can be granted. The practical used for the TPP can only apply for development that categorises in the operational works and material change of use (Arshad, 2015).

After independence from British in 1957, Malaysia has opted to adopt the British planning system as primary guidance to develop the nation. There are similarities pertaining to three main aspects of planning system (planning authority, development plan system and development control system) between Malaysia (Town and Country Planning Act 1976) and United Kingdom (Town and Country Planning Act 1990). In United Kingdom, approval of local development order is made by the local authority as stipulated under section $61 \mathrm{~A}$ of Town and Country Planning Act 1990. Before local authorities granted approval for a development order, the applicants are responsible to carry out preapplication consultation according to section $61 \mathrm{~W}$ of Town and Country Planning Act 1990. Temporary development order in United Kingdom is to allow flexibility in granting the development order to cope with the complexity of the 
Mohammad Yusup, Ahmad Fuzi Arshad, Marlyana Azyyati Marzukhi, \& Yusfida Ayu Abdullah

Temporary Planning Permission in Development Control System for Urban Development

development without neglecting the needs of having a conducive decisionmaking process in planning approval.

\section{The Process of Obtaining Temporary Planning Permission}

The process of obtaining the TPP is basically similar to the normal planning permission as in Figure 2 and follows the planning control process under Part IV of Act 172 and other related provisions. The only difference between TPP and normal planning permission are the time and scale of the development that should be allowed by LPA. Even though the TPP is just for a small scale, short-term development, the planning permission for this type of development must abide the same process including giving notice to adjacent landowners, planning appeal, development charge, revocation of planning approval, and planning enforcement. Yet, there is no extensive provision for the TPP mention in Act 172 except in Section 22(5). Further explanation will be described below.

\section{Provision to Use Temporary Planning Permission Based on Act 172}

The TPP has no extensive provision stipulated in Act 172 aside from Section 22(5) on the use of planning conditions, which states that planning permission granted on the use of land or building for a limited time and the use of such land and building will be reverted to its original use after the period expires. This is to ensure that the development of such land will be in accordance with the approved layout plan. As so, it is prohibited to carry out any development that may destruct land and environment in terms of physical, natural topography and landscape. The development should be sympathetic and integrated with surrounding architecture. Section 22(6) states that the copy of planning approval must be served to the persons that make objections to the proposed development according to Section 21(6) of Act 172.

\section{Requirements in Submitting Applications for Temporary Planning Permission} The requirements for TPP submission shall be as mentioned in Section 21 of Act 172:

- Layout plans, building plan, elevations, perspectives and etc.

- Planning proposal reports, environmental and social impact assessment

- Internal and external technical departments feed-back

- Supporting letters, power of attorney and documents

- Public and neighbouring landowner objections (Subsection 21(6))

- Processing fees for planning submission

\section{Appeal on the Planning Decision Based on Act 172}

The rights for planning appeal as in Section 23 is provided to the statutory person to forward an appeal to the Appeal Board, which are either the applicant of the planning permission or the rightful person that make objections under Section 
PLANNING MALAYSIA

Journal of the Malaysia Institute of Planners (2018)

21(6) who are upset by the decision or the condition imposed by the LPA. The Appeal Board shall hear the appellant and the LPA regarding the appeal and make a decision. The Appeal Board shall make decisions either by accepting the LPA decision and reject the appeal; allow the appeal and request of the LPA to grant approval or comply with conditions decided by the Appeal Board; allow the appeal and revoke the planning approval; allow the appeal and request the LPA to delete or amend the planning conditions or replace with conditions set by the Appeal Board.

\section{Revocation of Planning Approval}

The revocation or modification of the planning permission and approval by LPA usually being executed based on reason of public interest such as infrastructure development (highway, railway, etc.), which benefitted the public more than the individual or a small group of interest. The process of revocation is specified in Section 25(1) to Section 25(8) of Act 172. In overall process of revocation or modification, Section 25(9) states that any person that is upset by the amount of any reimbursement or compensation offered or paid, the respective person can appeal to the Appeal Board and the Board is responsible to assess the amount that shall be paid.

\section{Requisition Notice}

Requisition notice can be issued by the LPA or the owner of the land as in Section 30 of Act 172, based on the relevancy of the purpose of the requisition notice presented. Still, a person that aggrieved by the requisition notice submitted, with manners, shall appeal to the Appeal Board and then the process will go through as in Subsection 30(3) to Subsection 30(8) of Act 172.

\section{Planning Offences}

The categories of planning offences are highlighted in Section 26 to Section 29 of Act 172. The offences include development that is not in accordance with the local plan of the area, development being carried out without obtaining planning approval from the respective LPA of the area beforehand, development undertaken is not in accordance to the planning approval, carrying out development with approval being revoked, and development undertaken does not comply with the amended approval.

Decision-Making in Granting Temporary Planning Permission in Act 172, Planning Act (Cap. 232) and Town and Country Planning Act 1990

Section 22 of Act 172 provides on the treatment of applications. The LPA shall grant the planning permission within the capacity for its local authority area. However, in certain situation, the LPA needs to seek advice from the SPC and the NPPC regarding the application submitted, before granting or rejecting the 
Mohammad Yusup, Ahmad Fuzi Arshad, Marlyana Azyyati Marzukhi, \& Yusfida Ayu Abdullah

Temporary Planning Permission in Development Control System for Urban Development

application. The approval must be in accordance with the local plan of the area and if the proposed development is located in the area that has no local plan, the LPA shall notice the owners of the neighbouring land regarding the proposed development and the owners has the right to object, thus Section 21(7) applied. In addition, certain planning application may require following procedures according to Section 22(2), (2A) and (2B) together with the specified planning conditions as in Section 22(3) to Section 22(6).

In Singapore, the decision in granting the TPP falls under the jurisdiction 'competent authority', with the TPP provisions are set out in Part III: Development and Subdivision of Land of the Planning Act (Cap. 232). For the $\mathrm{UK}$, it is the LPA who is responsible in granting TPP in accordance to the provisions under the provisions of Part III: Control Over Development of the Town and Country Planning Act 1990.

\section{Instruments Use to Grant Temporary Planning Permission}

There are several instruments that can be used as medium and guidance in granting TPP. These include the existing policies and local plan of the area, compliance to planning standard, use class order (land and building), notice to adjacent landowners as pointed out in Section 21(6) of Act 172 (if applicable) and informal discussion by the LPA related to the planning application submitted.

Similarly, numerous instruments can be used under Planning Act (Cap. 232) to facilitate the process of TPP including obligation toward the provision in Master Plan and temporary levy as stipulated under Section 40(A). This section explains the needs of applicant to pay to the competent authority a tax known as temporary levy in respect of every development of land authorised by any planning permission or conservation granted for a specified period of 10 years or less.

In the UK, according to the Town and Country Planning (General Permitted Development) (England) Order 2015, Schedule 2, Part 4 Class D, "development consisting of a change of use of a building and any land within its curtilage; (a) from - (i) a use falling within Class A1 (shops), Class A2 (financial and professional services), Class A3 (restaurants and cafes), Class A4 (drinking establishment), Class A5 (hot food takeaways), Class B1 (business), Class D1 (non-residential institutions) and Class D2 (assembly and leisure) of the Schedule to the Use Classes Order, or , (ii) a use as a betting office or payday loan shop; (b) to a flexible use falling within Class A1 (shops), Class A2 (financial and professional services), Class A3 (restaurants and cafes) or Class B1 (business) of that Schedule. A temporary development order may be granted for a single continuous period of up to two (2) years beginning from the date the building and any land within its curtilage began to be used for the flexible use on the date given in the notice under paragraph D.2(a), whichever is earlier. 
PLANNING MALAYSIA

Journal of the Malaysia Institute of Planners (2018)

\section{Measures to Grant Temporary Planning Permission}

In granting TPP for any development of land and buildings, there are numerous aspects that need to be taken into consideration. Even though the TPP is just a short-term time-based development approval, it could have the possibility to affect the surrounding areas at an unpredictable time. There are possibilities of impact on planning standard and guidelines, existing and planned land use, local economy, the general public and socio-cultural, existing buildings, roads and traffic system, ecosystem and infrastructure and amenities.

According to Planning Act (Cap. 232), power to make rules relating to temporary development levy is provided under section 40D. The minister may make rules and for any matter which is required under this part to be prescribed and, in particular, for or with respect to all any of the following matters, including; (i) rates and methods of calculation; (ii) exemption of any particular development or class of developments from being subject of any temporary development levy; (iii) deferment of liability to pay any temporary development levy; and (iv) the refund, wholly or in part, of the temporary development levy paid by any person. This practice allows balance of power amongst the government authorities in the process of development control. Strict rules and regulations are needed to avoid any possible misconduct by both authority and the applicant in order to ensure effective planning control in Singapore.

Pre-consultation as in section $61 \mathrm{~W}$ in Town and Country Planning Act 1990 requires the application to be informed to relevant stakeholders to ensure thorough process in issuance of TPP. Additionally, section 62 further strengthens the power of LPA as responsible authority in facilitating the whole TPP process. This section elaborates the need of applicant to obligate towards the rules and regulations made by the LPA as part of stringent decision making process.

\section{Determination of Time Limit of Temporary Planning Permission}

Normally, the granting of TPP is based on the circumstances and considerations including existing planning policy, nature of the development activity based on time-frame, stipulated planning condition, a breach of the building use and the planning enforcement. Whereas, determination of time limit of the TPP is based on considerations such as the reversion to its original use, revocation of planning approval and the extension of planning approval (LPA may impose new planning condition and fees). For instance, Subang Jaya Municipal Council (MPSJ) imposed a maximum three-year limit for each TPP it approved. The decisions were made based on case-to-case basis and LPA has full jurisdiction over the decision on granting the planning approval subject to compliance to the rules and regulations made by the LPA.

The limit for TPP in Singapore is 10 years. Section 40C explain the meaning of temporary planning permission as "a planning permission or conservation permission granted for a specified period of 10 years or less". Also, 
Mohammad Yusup, Ahmad Fuzi Arshad, Marlyana Azyyati Marzukhi, \& Yusfida Ayu Abdullah

Temporary Planning Permission in Development Control System for Urban Development

the Minister may, in his discretion and subject to such terms and conditions as he may determine, remit, wholly or in part, the temporary development levy payable by any person if he is satisfied that it is just and equitable to do so.

\section{Use of Planning Conditions}

The use of comprehensive planning conditions by LPA is important to help in enhancing the efficiency of the current planning approval conditions. The criteria of planning conditions comprise:

- Necessity - consideration of the current and future demands and needs;

- Relevancy - pertinent to the current situation and conditions;

- Precision and clarity - transparent and understandable by people affected;

- Justice - seek fairness in every aspect of the decision-making process;

- Reasonableness - practicable, and

- Enforceable - long-term implementation.

\section{CONCLUSION}

TPP allows flexibility in the physical development, and undeniably required in the present planning and development control process as it is an important element in the urban planning system. It is, therefore, important that provisions regarding TPP in Act 172 are expanded in detail especially regarding time frame, type of development, development fees, and so on. The provisions related to TPP are also important for the purpose of planning legal system. The process and procedures, the process of decision-making, the use of formal and informal instruments and other measures need to be considered and should be uniformly formulated to be implemented by the LPA. Systematic and formal TPP process and procedures is an important measure that can help improve the competency of the delivery system of local authority in the development control process, particularly on submission for planning approval.

\section{ACKNOWLEDGEMENT}

The authors would like to credit the Research Management Centre (RMC) of Universiti Teknologi MARA, Malaysia and the Ministry of Higher Education Malaysia for the funding and continuous support to complete this study.

\section{REFERENCES}

Arshad, A. F. (2010). Paper 2: Development concept and development control. Shah Alam: Faculty of of Architecture, Planning and Surveying, UiTM.

Arshad, A. F. (2012). Flow chart of structure plan and local plan preparation as stipulated under Town and Country Planning Act 1976 (Act 172) (Unpublished). Universiti Technologi MARA, Malaysia.

Arshad, A. F. (2015). Kebenaran merancang terhad (Unpublished). Bengkel Pemantapan Dasar dan Kaedah Perancangan Negeri Kedah. Langkawi, Kedah, Malaysia. 
PLANNING MALAYSIA

Journal of the Malaysia Institute of Planners (2018)

Hong Kong Planning Department (2015). Hong Kong: The facts (town planning). Information Services Department, Hong Kong Special Administrative Region Government. Available at http://www.gov.hk.

Leicester City Council. (2015). A guide to making a planning application. Leicester: Author.

Planning Act (Chapter 232) (Singapore). Retrieved September 2018, from Singapore Institute Online: https://sso.agc.gov.sg/Act/PA1998?ValidDate=20170630\&ProvIds=legis\#legis

National Land Code Act 1965 (Act 56) (Malaysia).

The Town and Country Planning Act 1990 (England). Retrieved July 31, from legislation.gov.uk: http: //www/legislation.gov. uk/ukpga/1990/8/contents.

The Town and Country Planning (General Permitted Development) (England) Order 2015. Retrieved July 31, from legislation.gov.uk: http:www/legislation.gov.uk/uksi/2015/596/ contents/made.

Town and Country Planning Act 1976 (Act 172) (Malaysia).

Yusup, M. (2013). Statutory Procedure and Planning Machinery for Urban Development in Sarawak. Shah Alam: Universiti Teknologi MARA (Shah Alam).

Zainol, H. (2009). Perspektif perancangan. Shah Alam: Pusat Penerbitan Universiti (UPENA), UiTM. 